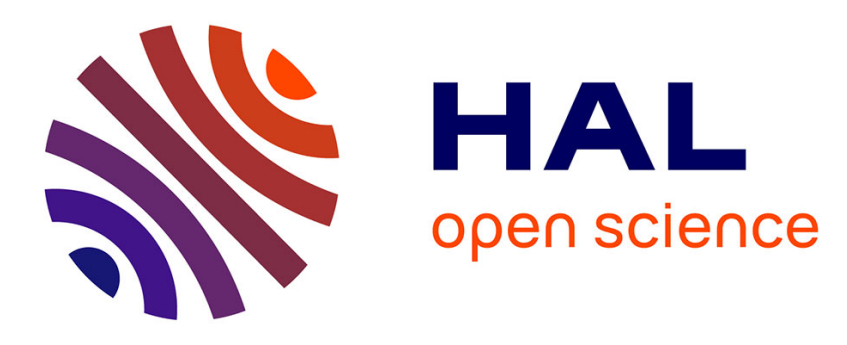

\title{
ERP Adoption and Use in Production Research: An Archival Analysis and Future Research Directions
}

Fosso Wamba Samuel, Jean Robert Kala Kamdjoug, Shahriar Akter, Kevin Carillo

\section{- To cite this version:}

Fosso Wamba Samuel, Jean Robert Kala Kamdjoug, Shahriar Akter, Kevin Carillo. ERP Adoption and Use in Production Research: An Archival Analysis and Future Research Directions. 17th Conference on e-Business, e-Services and e-Society (I3E), Oct 2018, Kuwait City, Kuwait. pp.539-556, 10.1007/978-3-030-02131-3_47. hal-02274161

\section{HAL Id: hal-02274161 \\ https://hal.inria.fr/hal-02274161}

Submitted on 29 Aug 2019

HAL is a multi-disciplinary open access archive for the deposit and dissemination of scientific research documents, whether they are published or not. The documents may come from teaching and research institutions in France or abroad, or from public or private research centers.
L'archive ouverte pluridisciplinaire HAL, est destinée au dépôt et à la diffusion de documents scientifiques de niveau recherche, publiés ou non, émanant des établissements d'enseignement et de recherche français ou étrangers, des laboratoires publics ou privés.

\section{(ㄷ)(i)}

Distributed under a Creative Commons Attribution| 4.0 International License 


\title{
ERP Adoption and Use in Production Research: An Archival Analysis and Future Research Directions
}

\author{
Samuel Fosso Wamba ${ }^{1}$, Jean Robert Kala Kamdjoug ${ }^{2}$, Shahriar Akter ${ }^{3}$ \\ and Kevin Carillo ${ }^{1}$ \\ ${ }^{1}$ Toulouse Business School, 1 Place Alphonse Jourdain, 31068 \\ Toulouse, France s.fosso-wamba@tbs-education.fr \\ ${ }^{2}$ Catholic University of Central Africa, B.P. 11628 Yaoundé, Cameroon \\ ${ }^{3}$ Sydney Business School, Faculty of Business, University of \\ Wollongong, Northfields Ave, Wollongong, NSW 2522, Australia
}

\begin{abstract}
The enterprise resource planning (ERP) adoption and use phenomenon has attracted much of the attention of production researchers over the last two to three decades. Through a systematic literature review, the purpose of this paper is to conduct a detailed examination of the investigation of ERP adoption and use in production research, more specifically. The paper provides a synthetic view of the various research approaches and designs having been used and presents an overview of the studied: vendors/systems, ERP deployment types, implementation outcomes, benefits, critical success factors, risk factors and effects based on identified 61 articles. Further research directions are proposed including the urgent need for researchers to examine ERP implementation with regards to IoT, big data analytics, machine learning and blockchain. The contribution of this study lies in the provided taxonomy, the detailed description of classifications, the adopted methodology, and the identification of research gaps.
\end{abstract}

Keywords: ERP, adoption and use, literature review, research agenda

\section{Introduction}

Running a business today is more and more difficult, especially with the evolving environment, the constant search for efficiency, and the more and more complex integration of sophisticated technologies. To manage a company effectively, the implementation of an Enterprise Resource Planning (ERP) system seems to be a logical and straightforward solution, provided it is wisely used. However, despite the promise of a high operational and strategic impact (if a sound business process analysis is performed), it remains challenging to easily familiarize with the use of ERPs (in order to manage computerised data exchanges) and to integrate software packages within them. As a result, ERPs have gradually become an important focus for a number of academic and corporate investigations over the past two to three 
decades. The existing literature on this subject has attributed several qualifiers to ERPs: the 'most strategic and most valuable tool with which to develop and improve a firm's competitiveness' (p. 94) [1]; the 'single biggest information technology (IT) investment an organisation can make' (p. 1037) [2]; a 'link through the entire supply chain aimed at best industry and management practices' (p. 537) [3]; the 'most widely accepted choices to obtain competitive advantage' (p. 397) [4]; and even the 'most difficult system development projects' (p.1236) [5]. The rationale behind such statements is that ERPs have thoroughly transformed modern-day businesses. Not only have they improved coordination and task efficiency [6] while standardising the flow of management information [1], they also have been able to provide a total integrated solution for the organisation's information-processing requests [2] and to facilitate inter-firm relationships [7].

According to [8], the global ERP market is expected to reach $\$ 41.69$ billion by 2020, with manufacturing \& services being the highest revenue generating segment. Also, forecasts indicate that new business functions and on-premise deployments will be the highest income generating segments shortly. North America is also forecast to be the highest revenue generating geographic region. According to Panorama's annual independent analysis of the titans of the ERP market from October 2015 to November 2016 [9], the distribution industry represents 35\% of the ERP market, followed by the manufacturing industry (29\%) and the education sector (23\%). They are mostly used by organisations with at least $\$ 50 \mathrm{M}$ in annual revenue. A total of $17 \%$ of the companies tend to implement ERPs to improve business performance, $14 \%$ to ensure compliance, $14 \%$ to make employees' jobs easier, and $13 \%$ to better integrate systems across locations. An important number of organisations (67\%) implement on-premise ERPs, 27\% implement them on demand (SaaS), and only 6\% implement cloud-based ERPs. This limited implementation of cloud-based ERP solutions is mainly due to the perceived risk of data losses (72\%) and security breaches (12\%). 70\% of organisations are reported to have customised $26-50 \%$ of the software code in their ERPs. $27 \%$ hired consultants to manage implementation, $22 \%$ to provide organisational change management support, and $19 \%$ to conduct unbiased software selection. While more than $70 \%$ of organisations focused on organisational change management, about $75 \%$ improved all their business processes. Despite the overall excitement and interest in ERPs at all levels, little effort has been done to organise the large bulk of ERP literature in a way that can facilitate research and enable a better understanding of the role of ERP systems in production. Thus, the purpose of this study is to provide an overview of our current body of literature on ERPs and to propose a structured classification framework that accurately depicts the state of ERP adoption and use research in production. The research objectives are set as follows:

1. Develop a classification framework to categorise the articles dealing with ERP adoption and use in production research;

2. Use the classification framework to classify and summarise all relevant articles;

3. Propose future research directions where the implementation and deployment of ERPs are likely to have significant impacts.

In the following section, we present the research materials and implemented research method. The results are then presented in a subsequent section. Finally, the 
results are discussed while we present their implications for research and practice, and provide future research directions.

\section{Methodology}

The methodological approach adopted for this study is a systematic literature review. The review process was developed based on those used by [10] on Big Data, [11] and [12] on ERP-related topics. The review process consisted of three steps: (i) developing a classification framework; (ii) conducting the literature review; and (iii) classifying and analysing the relevant journal articles. This classification framework focuses on journal articles dealing with topics related to the adoption and use of ERP in supply chain, production, and manufacturing. Specifically, seven dimensions related to ERP were used to build the framework: (i) research approach; (ii) system vendor; (iii) deployment type; (iv) implementation outcome; (v) benefits; (vi) risk factors and effects; and (vii) critical success factors. In this study, research approach refers to the plans and the procedures for research that span the steps from broad assumptions to detailed methods of data collection, analysis, and interpretation [13]. System vendor refers to the enterprise that manufactures or sells ERP systems or software. Deployment type refers to the hosting option chosen by a company using ERP functionalities to streamline operations. Implementation outcome refers to the effects of deliberate and purposive actions to implement ERP systems [14]. Benefits refers to the added value an organization expects or perceives after an ERP investment. Risk factors and effects refers to factors that create uncertainty in the ERP environment, the effects they may have on the organisation and the decisions made thereafter. Critical success factors refer to the key areas that management needs to focus on to achieve ERP performance goals. A broad literature search was conducted during the month of October 2017 looking for research articles having used the terms ERP or 'Enterprise Resource Planning' in their body. This search was restricted to the International Journal of Production Research because the authors considered it to be highly representative of the research conducted on ERPs in the field of production. Given the journal's fame and age, it is one of the oldest and most cited journals in the domain. At the end of the search, a total of 321 articles were selected, the abstracts and references of which were downloaded into EndNote reference management software while their full texts were downloaded into a computer for sorting, leading to the identification of 61 relevant articles for this study. Articles deemed irrelevant were discarded; and this was the case when ERP was not the main theme of the article or when it was cited superficially. The 61 articles were then classified into the seven dimensions of the framework. The classification process was rigorous but rather subjective. However, each author individually pegged each article into the framework dimensions, while disagreements were discussed during work sessions. Classification disagreements were resolved through votes. After justification, the authors voted on disagreements and the highest vote won. If there was a tie, the final decision was made by the principal investigator. 


\section{Results}

Figure 1 and Table 1 show that publications on ERP adoption and use in production research only started in 1999 with 1 article. In 2002, 5 publications on the topic were recorded, accounting for $8 \%$ of the total number of articles reviewed in this study. After a slight decrease in 2003 and 2004, an increase in publication volume was observed in 2005, with 7 articles published in the domain. The highest number of articles was recorded in 2007 (9 articles), which dropped significantly until 2012, where it stood at 8 articles. Since, then, the number of publications in the domain has dropped to 1 article by the end of 2016.

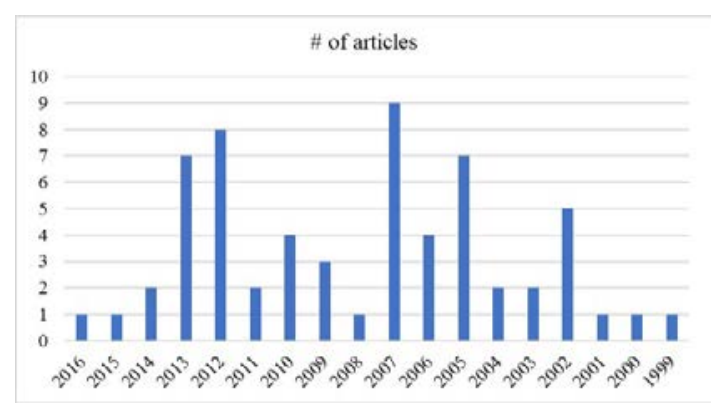

Fig. 1. Year of publication

As shown in Table 1, 28\% (17 of 61 articles) of publications on ERP adoption and use relied on a using mixed methods design. 21\% of the articles (13) were conceptual while 20\% (12 articles) adopted a non-conventional approach (e.g., ethnography, living laboratory...). Authors of $11 \%$ of articles (7) used case studies, $8 \%$ (5 articles) used literature reviews and experiments, and only $3 \%$ (2 articles) approached the topic using surveys.

Table 1. Classification by research approach

\begin{tabular}{llll}
\hline $\begin{array}{l}\text { Research } \\
\text { Approaches }\end{array}$ & Articles & $\begin{array}{l}\# \text { of } \\
\text { articles }\end{array}$ & \% \\
\hline Mixed methods & [15] survey + simulation model; [16]; [17]; & 17 & $28 \%$ \\
(e.g. survey + case & [18]; [19]; [20]; [21]; [22] survey + SEM; & & \\
study) & [23] survey + SEM; [24] Theoretical model & & \\
& \& case study; [25] Theoretical model \& case & & \\
& study; [26] Formal method + case study; [5] & \\
& Model + illustrative example; [27] & & \\
& Framework + case study; [28] Framework + & & \\
& case study; [29] Framework + simulation & & \\
& study; [30] Model + case study & & \\
[31]; [32]; [33]; [34]; [35]; [36]; [37]; [38]; & 13 & $21 \%$ \\
Conceptual & [39]; [40]; [41]; [42]; [43] & &
\end{tabular}


Others

(e.g., ethnography, living laboratory)
[44] literature review + interviews; [45] and industry'; [46] 'performance evaluation model' + empirical analysis; [47]

Algorithm creation + real data test; [48] New framework + numerical example + extensive analysis; [49] Discusses the limitations of SCOR analysis + case study; [50] Ontology and semantic integration in SAP ERP; [51] Fuzzy AHP methodology + case study; [52] Guidelines + case studies as examples; [53] Algorithm creation + case study; [54] Field study; [55] Two-stages approach: development of model \& numerical simulation

Case study [56]; [57]; [58]; [59]; [60]; [61]; [4]

[62]; [63]; [64]; [65]; [66]

Review

[67] model + simulation experiment; [68]

$8 \%$ model + simulation experiment; [69] model + simulation experiment; [70]; [71] simulation experiment

Survey [72]; [73] corresponding texts are separated by a semicolon. Only articles that need precision have texts next to them

Table 2 reveals that $74 \%$ (45 articles) of the reviewed articles do not focus on any specific ERP, as they only address general issues in relation to ERP and production. However, 15\% (9 articles) focus on SAP systems, and 3\% (2 articles) focus on Oracle ERPs. Also, 8\% (5 articles) of the publications focus on several ERPs for reasons such as comparison or integration. Of the 16 articles that addressed specific ERPs, 13 of them (21\% of the total number of articles reviewed) focused on ERPs deployed on premises (Table 3). Two articles (3\% of the total number of articles reviewed) dealt with software as a service (SaaS) ERPs, and only one ( $2 \%$ of the total number of articles reviewed) was about cloud-based ERP systems.

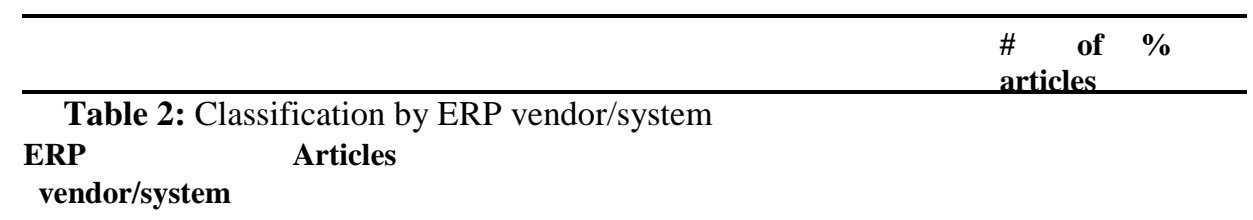




\begin{tabular}{|c|c|c|c|}
\hline Generic (N/A) & $\begin{array}{l}\text { [31]; [24]; [32]; [15]; [16]; [43]; [62]; [67]; [18]; } \\
\text { [44]; [63]; [34]; [64]; [68]; [56]; [29]; [35]; [45]; } \\
\text { [36]; [37]; [26]; [20]; [65]; [69]; [46]; [71]; [21]; } \\
\text { [47]; [48]; [66]; [49]; [39]; [40]; [41]; [22]; [51]; } \\
\text { [52]; [70]; [42]; [72]; [60]; [61]; [27]; [28]; [23] }\end{array}$ & 45 & $74 \%$ \\
\hline SAP & $\begin{array}{l}\text { [25] SAP R/3; [38] SAP R/3; [50]; [58]; [53]; [5] } \\
\text { SAP R/3; [59]; [55]; [30] SAP2 }\end{array}$ & 9 & $15 \%$ \\
\hline Several & $\begin{array}{l}\text { [19] SAP R/3, Mfg-PRO, BAAN; [4] Microsoft } \\
\text { Navision, SAP, Infor ERP system, Exact Globe } \\
\text { ERP; [73] BOPSE, SAP; [54]; [17] SAP, Oracle, } \\
\text { Baan, SSA, QAD/MFG PRO, JD Edwards }\end{array}$ & 5 & $8 \%$ \\
\hline Oracle & $\begin{array}{l}\text { [33] Oracle database, RDBMS, Developer /2000; } \\
\text { [57]; Oracle AIM }\end{array}$ & 2 & $3 \%$ \\
\hline & Total & 61 & $100 \%$ \\
\hline
\end{tabular}

Note: The texts correspond to the elements referred to in the citation. Each article and corresponding texts are separated by a semicolon. Only articles that need precision have texts next to them.

Table 3. Classification by Deployment Type

\begin{tabular}{|c|c|c|c|}
\hline $\begin{array}{l}\text { ERP } \\
\text { Deployment } \\
\text { Type }\end{array}$ & Articles & $\begin{array}{r}\text { \# of } \\
\text { articles }\end{array}$ & $\%$ \\
\hline On-premise & $\begin{array}{l}\text { [17]; [25]; [56]; [19]; [57]; [58]; [59]; [28]; [53]; } \\
\text { [5]; [30]; [55]; [4] }\end{array}$ & 13 & $81 \%$ \\
\hline SaaS & $\begin{array}{l}\text { [33] P: 2610-2611: ‘client/server structures’, } \\
\text { 'software application’; [27] P: 145/146: ‘ERPoutsource } \\
\text { process' }\end{array}$ & 2 & $13 \%$ \\
\hline Cloud-ERP & $\begin{array}{l}\text { [36] p5126: ‘web-based ERP component' } \\
\text { Total }\end{array}$ & $\begin{array}{l}1 \\
16\end{array}$ & $\begin{array}{l}6 \% \\
100 \%\end{array}$ \\
\hline
\end{tabular}

Note: The texts correspond to the elements referred to in the citation. Each article and corresponding texts are separated by a semicolon. Only articles that need precision have texts next to them

ERP benefits were classified (Table 4) according to the acknowledged framework developed by [74]. The analysis revealed that, operational ERP benefits are the most represented (28\%) in production research than any of the other benefits. The most prominent operational benefits are cost reduction (8\%), productivity improvement (8\%) and customer service improvement (7\%). Managerial benefits are the second most important category, accounting for $19 \%$ of the total number of identified ERP benefits, the most represented benefits being improved decision making and planning (8\%) and performance improvement (8\%). Strategic benefits (8\%), IT infrastructure benefits (4\%) and organisational benefits (4\%) benefits were the least represented categories. 
The well acknowledged risk factors and effects framework from [75] was used to analyse our pool of research outlets. Articles were classified in terms of both identified risk factors (Table 5) and risk effects (Table 6). Table 7 regroups risk effects into 'macro' risk classes. The main ERP risk factors that were identified include inadequate change management (8\%), inadequate selection (7\%), low top management involvement (7\%), inadequate BPR (7\%), ineffective consulting service (5\%), and inadequate IT system use (5\%). The corresponding risk effects include budget exceeds (10\%), poor business performance (8\%), time exceeds $(7 \%)$, project stop (5\%), and low degree of integration and flexibility (5\%). The classification by macro-level risk classes revealed that process failure, interaction failure and correspondence failure each make up $11 \%$ of the risk effects, while expectation failure accounted for $8 \%$.

Table 4. Classification by benefits

\begin{tabular}{|c|c|c|c|c|}
\hline Benefits & Sub benefits & Articles & $\begin{array}{r}\begin{array}{r}\text { \# of } \\
\text { articles }\end{array} \\
\end{array}$ & $\%$ \\
\hline \multirow{5}{*}{ Operational } & Cost reduction & $\begin{array}{l}\text { [67]; [69]; [48]; [72]; } \\
\text { [5] }\end{array}$ & 5 & $\overline{14 \%}$ \\
\hline & $\begin{array}{l}\text { Cycle time } \\
\text { reduction }\end{array}$ & {$[24]$} & 1 & $3 \%$ \\
\hline & $\begin{array}{l}\text { Productivity } \\
\text { improvement }\end{array}$ & $\begin{array}{l}\text { [57]; [45]; [19]; [5]. } \\
\text { [4] }\end{array}$ & 5 & $14 \%$ \\
\hline & $\begin{array}{l}\text { Quality } \\
\text { improvement }\end{array}$ & [19]; [16] & 2 & $5 \%$ \\
\hline & $\begin{array}{l}\text { Customer services } \\
\text { improvement }\end{array}$ & [43]; [67]; [45]; [57] & 4 & $11 \%$ \\
\hline \multirow[t]{2}{*}{ Managerial } & $\begin{array}{l}\text { Better resource } \\
\text { management }\end{array}$ & [43]; [16] & 2 & $5 \%$ \\
\hline & Improved decision & [56]; [35]; [45]; [47]; & 5 & $14 \%$ \\
\hline \multirow{7}{*}{ Strategic } & making and planning & {$[4]$} & & \\
\hline & $\begin{array}{l}\text { Performance } \\
\text { improvement }\end{array}$ & $\begin{array}{l}\text { [20]; [39]; [22]; [5]; } \\
\text { [16] }\end{array}$ & 5 & $14 \%$ \\
\hline & $\begin{array}{l}\text { Support business } \\
\text { growth }\end{array}$ & {$[4]$} & 1 & $3 \%$ \\
\hline & $\begin{array}{l}\text { Build business } \\
\text { innovations Build }\end{array}$ & {$[22]$} & 1 & $3 \%$ \\
\hline & cost leadership & [19] & 1 & $3 \%$ \\
\hline & $\begin{array}{l}\text { Build external } \\
\text { linkages (customers } \\
\text { and suppliers) }\end{array}$ & [38] & 1 & $3 \%$ \\
\hline & $\begin{array}{l}\text { Build business } \\
\text { flexibility for } \\
\text { current and future } \\
\text { changes }\end{array}$ & {$[22]$} & 1 & $3 \%$ \\
\hline
\end{tabular}




\begin{tabular}{lllll}
\hline & $\begin{array}{l}\text { Increased IT } \\
\text { infrastructure capability }\end{array}$ & {$[47]$} & 1 & $3 \%$ \\
& $\begin{array}{l}\text { Support organizational } \\
\text { changes }\end{array}$ & {$[17] 1$} & 1 & $3 \%$ \\
Organizational & {$[5]$} & 1 & $3 \%$ \\
& Empowerment & 37 & $\underline{100 \%}$ \\
\hline
\end{tabular}

Table 8 classifies the selected articles by critical success factors based on the factors identified by [44] and [46]. 23\% of the articles identify business process reengineering (BPR), system integration, and minimum software customization as critical success factors for ERP implementation projects. System flexibility and expansibility, and cross-department and cross-region application, are also regarded as critical success factors in $10 \%$ and $8 \%$ of articles respectively. The following factors was identified by exactly $7 \%$ of the reviewed articles: change management program and culture; compatibility between application structure and database; the professional capacity of consulting companies; project management; service quality level of consulting companies; support of top management; and training quality improvement.

Table 5. Classification by risk factors

\begin{tabular}{|c|c|c|c|}
\hline Risk factors & Articles & $\begin{array}{c}\text { \# of } \\
\text { articles }\end{array}$ & $\%$ \\
\hline Inadequate change management & $\begin{array}{l}{[16] ;[34] ;[45] ;[51] ;} \\
{[72]}\end{array}$ & 5 & $13 \%$ \\
\hline Inadequate selection & [16]; [44]; [5] & 4 & $10 \%$ \\
\hline Low top management involvement & [44]; [34]; [46]; [72] & 4 & $10 \%$ \\
\hline Inadequate BPR & [17]; [45]; [46]; [5] & 4 & $10 \%$ \\
\hline Ineffective consulting service & [56]; [19]; [5] & 3 & $8 \%$ \\
\hline Inadequate IT system use & {$[16],[44] ;[46]$} & 3 & $8 \%$ \\
\hline Poor team skills & {$[16] ;[44]$} & 2 & $5 \%$ \\
\hline Ineffective communication system & [44]; [46] & 2 & $5 \%$ \\
\hline Inadequate training and instruction & {$[56] ;[21]$} & 2 & $5 \%$ \\
\hline $\begin{array}{l}\text { Complex architecture and high number } \\
\text { of implementation modules }\end{array}$ & [34]; [45] & 2 & $5 \%$ \\
\hline Inadequate IT system maintainability* & [44]; [56] & 2 & $5 \%$ \\
\hline Low key user involvement & {$[72]$} & 1 & $3 \%$ \\
\hline Bad managerial conduct & [44] & 1 & $3 \%$ \\
\hline $\begin{array}{l}\text { Ineffective project management } \\
\text { techniques }\end{array}$ & {$[44]$} & 1 & $3 \%$ \\
\hline $\begin{array}{l}\text { Inadequate legacy system } \\
\text { management }\end{array}$ & [16] & 1 & $3 \%$ \\
\hline Poor leadership & [44] & 1 & $3 \%$ \\
\hline
\end{tabular}


Inadequate IT supplier stability and

1

$3 \%$

performances

Total

39

$100 \%$

Table 6. Classification by risk effects

\begin{tabular}{|c|c|c|c|}
\hline Risk effects & Articles & $\begin{array}{c}\text { \# of } \\
\text { articles }\end{array}$ & $\%$ \\
\hline Budget exceed & $\begin{array}{l}\text { [16]; [44]; [56]; [45]; [71]; } \\
\text { [21]; }\end{array}$ & 6 & $24 \%$ \\
\hline Poor business performance & [17]; [19]; [46]; [48]; [22] & 5 & $20 \%$ \\
\hline Time exceed & [44]; [56]; [45]; [21] & 4 & $16 \%$ \\
\hline Project stop & [16]; [45]; [4] & 3 & $12 \%$ \\
\hline $\begin{array}{l}\text { Low degree of integration and } \\
\text { flexibility }\end{array}$ & [48]; [40]; [51] & 3 & $12 \%$ \\
\hline $\begin{array}{l}\text { Bad financial /ecor } \\
\text { performance organisation }\end{array}$ & $c[40,48]$ & 2 & $8 \%$ \\
\hline $\begin{array}{l}\text { Low organisation and process } \\
\text { fitting }\end{array}$ & [48] & 1 & $4 \%$ \\
\hline Low strategic goals fitting & {$[48]$} & 1 & $4 \%$ \\
\hline \multicolumn{2}{|c|}{ Total } & 25 & $\underline{100 \%}$ \\
\hline
\end{tabular}

Table 7. Classification by risk effect macro-classes

\begin{tabular}{llll}
\hline $\begin{array}{l}\text { Risk effects - } \\
\text { Macro-Classes }\end{array}$ & Articles & $\begin{array}{l}\text { \# of } \\
\text { articles }\end{array}$ & \% \\
\hline $\begin{array}{l}\text { Process failure } \\
\text { Interaction failure }\end{array}$ & [16]; [44]; [56]; [45]; [71]; [21]; [4] & 7 & $27 \%$ \\
$\begin{array}{l}\text { Correspondence } \\
\text { failure }\end{array}$ & [17]; [19]; [46]; [48]; [22]; [40]; [51] & 7 & $27 \%$ \\
$\begin{array}{l}\text { Expectation } \\
\text { failure }\end{array}$ & [17]; [19]; [46]; [48]; [22] & 5 & $19 \%$ \\
& Total & & \\
& & 26 & $100 \%$ \\
\hline
\end{tabular}

Table 8. Classification by critical success factors

\begin{tabular}{llll}
\hline CSF & Articles & $\begin{array}{l}\text { \# of } \\
\text { articles }\end{array}$ & \% \\
\hline $\begin{array}{l}\text { BPR, integration, } \\
\text { minimum customization }\end{array}$ & $\begin{array}{c}\text { and[31]; [16]; [17]; [44]; [34]; [64]; } \\
\text { [36]; [46]; [57]; [66]. }\end{array}$ & 14 & $15 \%$ \\
$\begin{array}{l}\text { [49]; [39]; [51]; [52] } \\
\text { System flexibility \& }\end{array}$ & $\begin{array}{l}\text { [24]; [17]; [36]; [46]; [66]; } \\
\text { [39] }\end{array}$ & 6 & $7 \%$ \\
$\begin{array}{l}\text { expansibility } \\
\text { Cross-department \& cross- }\end{array}$ & {$[16] ;$ [67]; [64]; [20]; [46] } & 5 & $5 \%$
\end{tabular}




\begin{tabular}{|c|c|c|c|}
\hline \multicolumn{2}{|c|}{$\begin{array}{l}\text { Change management [24]; [16]; [44]; [28] } \\
\text { program and culture }\end{array}$} & 4 & $4 \%$ \\
\hline $\begin{array}{l}\text { Compatibility between } \\
\text { application structure \& } \\
\text { database }\end{array}$ & [16]; [67]; [34]; [46] & 4 & $4 \%$ \\
\hline $\begin{array}{l}\text { Professional capacity of } \\
\text { consulting company }\end{array}$ & [31]; [16]; [46]; [72] & 4 & $4 \%$ \\
\hline Project management & [31]; [16]; [44]; [38] & 4 & $4 \%$ \\
\hline $\begin{array}{l}\text { Service quality level of } \\
\text { consulting company }\end{array}$ & [16]; [46]; [5]; [76] & 4 & $4 \%$ \\
\hline $\begin{array}{l}\text { Support of top } \\
\text { management }\end{array}$ & [16]; [44]; [46]; [72] & 4 & $4 \%$ \\
\hline $\begin{array}{l}\text { Training quality } \\
\text { improvement }\end{array}$ & [34]; [56]; [46]; [39] & 4 & $4 \%$ \\
\hline $\begin{array}{l}\text { Adjustment of the interr } \\
\text { organisation structure }\end{array}$ & $\operatorname{al}[46] ;[66] ;[54]$ & 3 & $3 \%$ \\
\hline $\begin{array}{l}\text { Software development, } \\
\text { testing, and troubleshooting }\end{array}$ & [44]; [5]; [25] & 3 & $3 \%$ \\
\hline Cost of implementation & [56]; [47]; [72] & 3 & $3 \%$ \\
\hline Information quality & [65]; [5]; [76] & 3 & $3 \%$ \\
\hline Business plan and vision & [16]; [44] & 2 & $2 \%$ \\
\hline $\begin{array}{l}\text { Communication } \\
\text { consulting company }\end{array}$ & th[46]; [5] & 2 & $2 \%$ \\
\hline $\begin{array}{l}\text { Development of ERP } \\
\text { implementation strategies }\end{array}$ & [64]; [46] & 2 & $2 \%$ \\
\hline $\begin{array}{l}\text { Implementation rationality } \\
\text { checking }\end{array}$ & [24]; [46] & 2 & $2 \%$ \\
\hline $\begin{array}{l}\text { IT system quality of the } \\
\text { supplier }\end{array}$ & [46]; [65] & 2 & $2 \%$ \\
\hline Project champion & [16]; [44] & 2 & $2 \%$ \\
\hline System capability & [17]; [46] & 2 & $2 \%$ \\
\hline $\begin{array}{l}\text { Technology alignment } \\
\text { with business } \\
\text { processes and needs }\end{array}$ & [34]; [45] & 2 & $2 \%$ \\
\hline $\begin{array}{l}\text { Choice of software \& } \\
\text { vendor }\end{array}$ & [19]; [76] & 2 & $2 \%$ \\
\hline $\begin{array}{l}\text { Monitoring and evaluation o } \\
\text { performance }\end{array}$ & $f[44]$ & 1 & $1 \%$ \\
\hline $\begin{array}{l}\text { Improvement of personnel } \\
\text { cooperation and adaptation }\end{array}$ & {$[46]$} & 1 & $1 \%$ \\
\hline Objective management & {$[46]$} & 1 & $1 \%$ \\
\hline Teamwork and & {$[72]$} & 1 & $1 \%$ \\
\hline
\end{tabular}


composition

$\begin{array}{lccc}\text { Implementation time and } & {[56]} & 1 & 1 \% \\ \text { ROI } & & & 1 \% \\ \begin{array}{l}\text { Proper resource allocation } \\ \text { System usefulness }\end{array} & {[45]} & 1 & 1 \% \\ \begin{array}{l}\text { Capacity of internal IT } \\ \text { personnel }\end{array} & {[55]} & 1 & 1 \% \\ & \text { Total } & 1 & 100 \%\end{array}$

\section{Discussion}

The first direct observation that can be made from this literature review is that journal publications on ERP adoption and use started in production research by 1999 and became very popular in 2007. Following a rather constant decrease during the four subsequent years, another peak of publications occurred in 2012 and 2013. Given that this study is based on a single journal, it is possible that this contradictory development in the results is due to number of publications accepted by the journal each year. With the proliferation of articles on ERP, many journals became more critical about the articles they accept on the topic to avoid redundancies.

Most of the studies on the topic were conducted using a mixed-methods approach. This research design has the benefit of being able to address confirmatory and exploratory research questions simultaneously and provide stronger inference than a single method [77]. The application of this approach in the study of ERP adoption and use in production research, has helped to develop a deep understanding and to inductively generate new theoretical insights on the subject. The identified articles having relied on such approach opted for a combination of surveys with simulations, case studies and structural equation models (SEM). Others combined frameworks and models with simulations, illustrative examples and case studies. Conceptual papers were the second most represented category. Such studies typically aimed at focusing on identifying and defining ideas related to the topic, thus helping the readers to better understand the principles or generalizations regarding different aspects of ERP adoption and use. A number of papers relying on less 'conventional' approaches such as algorithm creation, performance evaluation models, and fuzzy AHP methodology, were also identified.

Most of the literature that was reviewed did not focus on specific ERP vendors or systems. This may be attributed to the fact that most papers concentrated on factors affecting the adoption and use of ERP and its integration with production units irrespective of the vendor. However, among the articles dealing with specific ERPs, SAP ERPs were the most popular systems under investigation. There were also several publications on different ERP types, especially in the area of the integration of 
multiple ERPs into companies' production processes. Nowadays, organisations tend to prefer ERP systems to be deployed on-premise or on-demand (SaaS). In this review, most of the ERPs that were studied relied on on-premise deployment even though on-demand solutions have become trendy and very cost-effective compared to on-premise solutions. Data security and customization have remained major concerns regarding the implementation of on-demand solutions [78] [79]. Therefore, the choice to integrate production processes through either on-premise or cloud-based ERPs has remained a matter of business priorities between high levels of customization and security (onpremises) or low operational cost (SaaS) [80].

Most of the reviewed papers did not focus on the implementation outcomes of ERPs in production, addressing only other aspects such as requirements, selection, adoption, integration, and planning. However, all the publications that provided information on ERP implementation clearly indicated positive outcomes in terms of implementation. The main implication that can be drawn from such result is that there is to date no research on failed ERP projects in production. Research efforts in this area need to be encouraged and welcome as they could provide important insights about the other side of the ERP implementation coin.

Our results fully corroborate with [81] who found that the benefits of ERP adoption and use in production are mostly operational and managerial, and that there were no significant benefits in terms of IT infrastructure and organisation. The main operational benefits include product improvement, cost reduction, and customer service improvement. ERPs are very instrumental in Product Lifecycle Management (PLM), providing operational benefits as indicated above [82]. There are also managerial benefits such as performance improvement and improved decision-making planning. ERP vendors today have started adding business intelligence (BI) capabilities to their ERP systems to meet the needs of companies who seek to make the most of their data [83]. This adds substantial value to ERPs since this allows the access of information on production processes directly from ERP modules and provides performance insights in real time [84].

When analysing the risk factors and effects of ERP adoption and use, six main risk factors were recurrently observed: inadequate change management, inadequate ERP selection, low top management involvement, inadequate Business Process Reengineering (BPR), ineffective consulting service, and inadequate IT system use. These factors lead mostly to process, interaction and correspondence failures. The main effects of these risks on a company range from budget exceed, poor business performance and time exceed to project stop and low degree of integration and flexibility. Further studies could be carried out based on these results to more clearly identify the existence of dependencies between these factors [75]. In this study, the most represented critical success factors (CSF) are BPR, integration and minimum customization, and system flexibility and expansibility. Indeed, BPR, system integration, and customization are well-known CSFs in ERP implementation [85], [86]. However, system flexibility and expansibility do not appear in a majority of ERP CSF frameworks. This highlights their rather ignored but particular importance in the specific context of production processes. 


\section{Conclusion and Future Research Directions}

There remains a number of limitations that need to be taken into consideration. One is that the study is based solely on articles from the International Journal of Production Research. Our results thus provide a representative but imprecise depiction of ERP adoption and use research in the production field. Furthermore, despite the rigorous sorting of identified papers, their selection and classification remains subjective to some extent. The authors have done their best at mitigating the risks and biases that such relative subjectivity could engender.

Overall, this systematic review offers a clear overview of the current body of knowledge on ERP adoption and use in production. Firstly, this research contributes to research and management perspectives, emphasizing the importance of ERP adoption and use in production and enabling a better understanding of the role and impact of ERPs in production. Secondly, the study presents a general taxonomy for ERP adoption and use and identifies key elements that are relevant to production research. Finally, managers at all level are offered critical insights for the formulation and execution of ERP implementation strategies during operations. The proposed classification framework can be used by companies to address issues ranging from the selection of the right ERP system and the right ERP deployment type to the planning of risk management strategies. The research findings show that managers can implement ERP systems for production operations and have successful outcomes. This research work can eventually help managers to better grasp the most relevant benefits of ERP adoption and use, the related CSFs, and the associated risks to be overcome in the area of production.

Moreover, it is in the interest of managers and researchers to recognise the contribution of ERP systems in production and to assess changes in operational performance at both the modular and the system levels [87]. In fact, present-day ERP system can catalyse the application of lean production practices [88]. Some even suggest that managers should first adopt an ERP as the backbone of company operations before deploying any other enterprise systems (ES), such as SCM systems [81]. Thus, further research is needed on the adoption of modern ERPs to meet their operational requirements in other areas.

One of the major contributions of this paper is to set out a systematic review which results can be used by managers to improve ERP adoption and use in production environments. It shows the current state of research on the topic, proposing other research angles for future studies. Organizations could enjoy several operational and managerial benefits through the successful adoption and use of ERPs for production. They could leverage the information ecosystem created by ERPs to improve their products and reduce cost through supply chain optimization and improved customer services. This study also identified many aspects of ERP adoption and use that can be explored in the area of production and beyond. For example, the development of a comprehensive conceptual framework is needed to fully and efficiently capture the business value that can be derived from the adoption and use of ERPs. Future research may also consider developing explanatory and predictive theories related to BPR, ERP deployment, performance, and decision-making process. 
The contribution of this study lies in that it establishes a taxonomy of publications on ERPs in the domain of production, provides a detailed description of core aspects in this regard, and sets out an efficient methodology to be followed. Besides, it identified research gaps and proposed research questions. The review and developed taxonomy should serve as a starting point for the development of more up-to-date and improved insights on the topic. Legacy issues or areas having had limited attention, such as IoT, big data, machine learning and blockchain, are clearly identified and should be the focus of future research. Furthermore, the research perspectives highlighted in Table 9 can be extended and used in the development of a research agenda for future studies in this domain. We conclude by emphasizing the urgent need for more research efforts on ERP deployment types and implementation outcomes, as organisations need such information to replicate best practices and avoid pitfalls. This will be very useful for managers seeking to optimize organisational performance, competitive advantage, and business results during implementation.

\section{Table 9: Future research questions for ERP studies}

\begin{tabular}{|c|c|c|}
\hline \begin{tabular}{l}
\multicolumn{1}{c}{ ERP } \\
research \\
streams
\end{tabular} & $\begin{array}{l}\text { Relevant } \\
\text { theories }\end{array}$ & $\begin{array}{l}\text { Future Research Questions for ERP in } \\
\text { production research }\end{array}$ \\
\hline $\begin{array}{l}\text { Strategy, } \\
\text { culture, } \\
\text { leadership, } \\
\text { and } \\
\text { organizatio } \\
\text { n }\end{array}$ & \begin{tabular}{l}
\multicolumn{1}{c}{ Resource } \\
based theory [89], \\
Competitive \\
strategy [90], \\
dynamic \\
capability theory \\
[91]
\end{tabular} & $\begin{array}{l}\text { How can organizations ensure business alignment, } \\
\text { ERP and strategic analytics in the emerging data } \\
\text { economy? } \\
\text { Which ERP architecture will lead to the competitive } \\
\text { advantage in the IoT landscape? } \\
\text { How can organizations develop capabilities in IoT, } \\
\text { big data, machine learning and blockchain to } \\
\text { leverage digital transformation? } \\
\text { How can dynamic analytics capabilities be } \\
\text { developed using big data to address uncertainty? }\end{array}$ \\
\hline $\begin{array}{l}\quad \text { Informat } \\
\text { ion systems } \\
\text { and } \\
\text { technology } \\
\text { managemen } \\
\text { t }\end{array}$ & $\begin{array}{l}\text { Transaction cost } \\
\text { theory [92, } \\
\text { 93] }\end{array}$ & $\begin{array}{l}\text { What are the key issues related to the design of } \\
\text { various interfaces between ERP and IoT-enabled } \\
\text { connected devices? } \\
\text { What is the impact of ERP on lean operations and } \\
\text { quality management? } \\
\text { How can organizations better use insights from } \\
\text { ERP and relevant analytics to achieve operational } \\
\text { excellence? } \\
\text { What is the impact of ERP and analytics in various } \\
\text { sectors (e.g., healthcare, retail industry, and } \\
\text { manufacturing)? }\end{array}$ \\
\hline
\end{tabular}




\begin{tabular}{|c|c|c|}
\hline \begin{tabular}{l}
\multicolumn{1}{c}{ Data } \\
quality, \\
cloud \\
infrastructur \\
e, privacy \\
and \\
security, \\
blockchain
\end{tabular} & \begin{tabular}{l}
\multicolumn{1}{c}{ IT quality } \\
theory [94], IS \\
success theory \\
[95, 96], \\
Sociomateriality \\
of IT [97]
\end{tabular} & $\begin{array}{l}\text { What factors influence governance, security, and } \\
\text { privacy in the next generation ERP? } \\
\text { How can a firm leverage ERP to generate, acquire, } \\
\text { transform and integrate big data? } \\
\text { How can a firm leverage a cloud-based platform to } \\
\text { produce data and business value? } \\
\text { How ERP can be used to develop data-driven } \\
\text { innovations? } \\
\text { Should firms continue with the dominant } \\
\text { onpremise ERP strategy or move toward ERP as } \\
\text { SaaS or a cloud-based ERP system? }\end{array}$ \\
\hline $\begin{array}{l}\text { Overarc } \\
\text { hing value }\end{array}$ & \begin{tabular}{l}
\multicolumn{1}{c}{ IT business } \\
value [98], business \\
value of analytics \\
[99]
\end{tabular} & $\begin{array}{l}\text { How do ERP-integrated analytics, machine learning } \\
\text { and blockchain influence each other to enhance } \\
\text { competitive advantage? } \\
\text { How do organizations deal with ERP } \\
\text { implementation to diversify themselves? } \\
\text { How do organizations capitalize on ERP to extract } \\
\text { value? }\end{array}$ \\
\hline & & $\begin{array}{l}\text { What factors influence ERP implementation at } \\
\text { different stages? }\end{array}$ \\
\hline
\end{tabular}

\section{References}

1. Pan, M.-J. and W.-Y. Jang, Determinants of the adoption of enterprise resource planning within the technology-organization-environment framework: Taiwan's communications industry. Journal of Computer information systems, 2008. 48(3): p. 94-102.

2. Dezdar, S. and A. Sulaiman, Successful enterprise resource planning implementation: taxonomy of critical factors. Industrial Management \& Data Systems, 2009. 109(8): p. 1037-1052.

3. Momoh, A., R. Roy, and E. Shehab, Challenges in enterprise resource planning implementation: state-of-the-art. Business Process Management Journal, 2010. 16(4): p. 537-565.

4. Powell, D., J. Riezebos, and J.O. Strandhagen, Lean production and ERP systems in small- and medium-sized enterprises: ERP support for pull production. International Journal of Production Research, 2013. 51: p. 395409.

5. Moalagh, M. and A.Z. Ravasan, Developing a practical framework for assessing ERP post-implementation success using fuzzy analytic network process. International Journal of Production Research, 2013. 51: p. 12361257.

6. Chou, S.-W. and Y.-C. Chang, The implementation factors that influence the ERP (enterprise resource planning) benefits. Decision Support Systems, 2008. 46(1): p. 149-157. 
7. Esteves, J., A benefits realisation road-map framework for ERP usage in small and medium-sized enterprises. Journal of 35. Enterprise Information Management, 2009. 22(1/2): p. 25-

8. Allied Market Research, ERP Software Market by Deployment (On-premise deployment and Cloud deployment) and Function (Finance, Human resource, Supply chain and Others) - Global Opportunity Analysis and Industry Forecast, 2013 - 2020. 2018.

9. $\quad$ Panorama, C.s., 2017 Report on ERP Systems \& Enterprise Software. 2017.

10. Wamba, S.F., et al., How 'big data'can make big impact: Findings from a systematic review and a longitudinal case study. International Journal of Production Economics, 2015. 165: p. 234-246.

11. Tarhini, A., H. Ammar, and T. Tarhini, Analysis of the critical success factors for enterprise resource planning implementation from stakeholders' perspective: A systematic review. International Business Research, 2015. 8(4): p. 25.

12. Haddara, M. and O. Zach. ERP systems in SMEs: A literature review. in System Sciences (HICSS), 2011 44th Hawaii International Conference on. 2011. IEEE.

13. Creswell, J.W. and J.D. Creswell, Research design: Qualitative, quantitative, and mixed methods approaches. 2017: Sage publications.

14. Proctor, E., et al., Outcomes for implementation research: conceptual distinctions, measurement challenges, and research agenda. Administration and Policy in Mental Health and Mental Health Services Research, 2011. 38(2): p. 65-76.

15. Koh, S.C.L. and S.M. Saad, Development of a business model for diagnosing uncertainty in ERP environments. International Journal of Production Research, 2002. 40: p. 3015-3039.

16. Kumar, V., B. Maheshwari, and U. Kumar, Enterprise resource planning systems adoption process: A survey of Canadian organizations. International Journal of Production Research, 2002. 40: p. 509-523.

17. Gattiker, T.F. and D.L. Goodhue, Software-driven changes to business processes: An empirical study of impacts of Enterprise Resource Planning (ERP) systems at the local level. International Journal of Production Research, 2002. 40: p. 4799-4814.

18. Craighead, C.W. and R.L. Laforgej, Taxonomy of information technology adoption patterns in manufacturing firms. International Journal of Production Research, 2003. 41: p. 2431-2449.

19. Ayă̆, Z. and R.G. Özdemİ, An intelligent approach to ERP software selection through fuzzy ANP. International Journal of Production Research, 2007. 45: p. 2169-2194.

20. Gattiker, T.F., Enterprise resource planning (ERP) systems and the manufacturing-marketing interface: an information-processing theory view. International Journal of Production Research, 2007. 45: p. 2895-2917. 
21. Irani, Z., A.M. Sharif, and P.E.D. Love, Knowledge mapping for information systems evaluation in manufacturing. International Journal of Production Research, 2007. 45: p. 2435-2457.

22. Schniederjans, M.J., Q. Cao, and V. Ching Gu, An operations management perspective on adopting customer-relations management (CRM) software. International Journal of Production Research, 2012. 50: p. 3974-3987.

23. Migdadi, M.M. and M.K.S.A. Zaid, An empirical investigation of knowledge management competence for enterprise resource planning systems success insights from Jordan. International Journal of Production Research, 2016. 54(18): p. 5480-5498.

24. Teltumbde, A., A framework for evaluating ERP projects. International Journal of Production Research, 2000. 38: p. 4507-4520.

25. Ioannou, G. and C. Papadoyiannis, Theory of constraints-based methodology for effective ERP implementations. International Journal of Production Research, 2004. 42: p. 4927-4954.

26. Lian, Y.H. and H. Van Landeghem, Analysing the effects of Lean manufacturing using a value stream mapping-based simulation generator. International Journal of Production Research, 2007. 45: p. 3037-3058.

27. Zandi, F., A bi-level constraint-oriented outsourcing framework for orchestration of an ERP system. International Journal of Production Research, 2014. 52: p. 130-148.

28. Wu, W.-H., et al., An advanced CMII-based engineering change management framework: the integration of PLM and ERP perspectives. International Journal of Production Research, 2014. 52: p. 6092-6109.

29. Xu, H.Q., et al., A Web-based system for manufacturing co-ordination in complex supply networks. International Journal of Production Research, 2005. 43: p. 2049-2070.

30. Zhang, L.L., E. Vareilles, and M. Aldanondo, Generic bill of functions, materials, and operations for SAP2configuration. International Journal of Production Research, 2013. 51: p. 465-478.

31. Ng, J.K.C., W.H. Ip, and T.C. Lee, A paradigm for ERP and BPR integration. International Journal of Production Research, 1999. 37: p. 20932108.

32. Shtub, A., A framework for teaching and training in the Enterprise Resource Planning (ERP) era. International Journal of Production Research, 2001. 39: p. 567-576.

33. Zhou, X., et al., Development of a financial management system in a CIMS environment. International Journal of Production Research, 2005. 43: p. 26032613.

34. Park, K. and A. Kusiak, Enterprise resource planning (ERP) operations support system for maintaining process integration. International Journal of Production Research, 2005. 43: p. 3959-3982.

35. Gupta, A., H. Lödding, and M.M. Tseng, An approach of capability representation for improving capacity planning. International Journal of Production Research, 2006. 44: p. 3419-3431. 
36. Wang, Z.J., X.F. Xu, and D.C. Zhan, Component reuse based agile reconfiguration for Enterprise Resource Planning (ERP) systems in manufacturing enterprises. International Journal of Production Research, 2006. 23: p. 5107-5129.

37. Segerstedt, A., Master Production Scheduling and a comparison of Material Requirements Planning and cover-time planning. International Journal of Production Research, 2006. 44: p. 3585-3606.

38. Samaranayake, P. and D. Toncich, Integration of production planning, project management and logistics systems for supply chain management. International Journal of Production Research, 2007. 45: p. 5417-5447.

39. Kahraman, C., A. Beskese, and I. Kaya, Selection among ERP outsourcing alternatives using a fuzzy multi-criteria decision making methodology. International Journal of Production Research, 2010. 48: p. 547-566.

40. $\mathrm{Wu}$, L.-C. and F.-M. Liou, A quantitative model for ERP investment decision:

considering revenue and costs under uncertainty. International Journal of Production Research, 2011. 49: p. 6713-6728.

41. Feng, K., U.S. Rao, and A. Raturi, Setting planned orders in master production scheduling under demand uncertainty. International Journal of Production Research, 2011. 49.

42. Jodlbauer, H. and S. Reitner, Material and capacity requirements planning with dynamic lead times. International Journal of Production Research, 2012. 50: p. 4477-4492.

43. Pechoucek, M., et al., ExPlanTech: Applying multi-agent systems in production planning. International Journal of Production Research, 2002. 40: p. 3681-3692.

44. Loh, T.C. and S.C.L. Koh, Critical elements for a successful enterprise resource planning implementation in small-and medium-sized enterprises. International Journal of Production Research, 2004. 42: p. 3433-3455.

45. Quiescenti, M., et al., Business process-oriented design of Enterprise Resource Planning (ERP) systems for small and medium enterprises. International Journal of Production Research, 2006. 44: p. 3797-3811.

46. Yang, C.-C., et al., The use of fuzzy measures in a performance-evaluation model for ERP implementation among Taiwanese semiconductor manufacturers. International Journal of Production Research, 2007. 45: p. 4735-4752.

47. Zobolas, G.I., C.D. Tarantilis, and G. Ioannou, Extending capacity planning by positive lead times and optional overtime, earliness and tardiness for effective master production scheduling. International Journal of Production Research, 2008. 46: p. 3359-3386.

48. Kim, J., Activity-based framework for cost savings through the implementation of an ERP system. International Journal of Production Research, 2009. 47: p. 1913-1929. 
49. Wang, W.Y.C., H.K. Chan, and D.J. Pauleen, Aligning business process reengineering in implementing global supply chain systems by the SCOR model. International Journal of Production Research, 2010. 48: p. 5647-5669.

50. Grüninger, M., et al., Combining RFID with ontologies to create smart objects. International Journal of Production Research, 2010. 48: p. 26332654.

51. Sarfaraz, A., K. Jenab, and A.C. D'Souza, Evaluating ERP implementation choices on the basis of customisation using fuzzy AHP. International Journal of Production Research, 2012. 50: p. 7057-7067.

52. Framinan, J.M. and R. Ruiz, Guidelines for the deployment and implementation of manufacturing scheduling systems. International Journal of Production Research, 2012. 50: p. 1799-1812.

53. Baker, T. and V. Jayaraman, Managing information and supplies inventory operations in a manufacturing environment. Part 2: An order-timing and sizing algorithm. International Journal of Production Research, 2012. 50: p. 1767-1779.

54. Ifinedo, P. and D.H. Olsen, An Empirical Research on the Impacts of organisational decisions' locus, tasks structure rules, knowledge, and IT function's value on ERP system success. International Journal of Production Research, 2015. 53: p. 2554-2568.

55. Samaranayake, P., Improving manufacturing lead time using holistic approach to planning and execution with integrated data structures: numerical simulation and comparison. International Journal of Production Research, 2013. 51: p. 4484-4501.

56. Dowlatshahi, S., Strategic success factors in enterprise resource-planning design and implementation: a case-study approach. International Journal of Production Research, 2005. 43: p. 3745-3771.

57. Liu, C.M. and L.S. Chen, Applications of RFID technology for improving production efficiency in an integrated-circuit packaging house. International Journal of Production Research, 2009. 47: p. 2203-2216.

58. Lebreton, B.G.M., L.N. Van Wassenhove, and R.R. Bloemen, Worldwide sourcing planning at Solutia's glass interlayer products division. International Journal of Production Research, 2010. 48: p. 801-819.

59. Chou, Y.-C., C.-H. Lu, and Y.-Y. Tang, Identifying inventory problems in the aerospace industry using the theory of constraints. International Journal of Production Research, 2012. 50: p. 4686-4698.

60. Cheng, C.-Y., et al., Application of fault tree analysis to assess inventory risk:

a practical case from aerospace manufacturing. International Journal of Production Research, 2013. 51: p. 6499-6514.

61. Netland, T., Exploring the phenomenon of company-specific production systems: one-best-way or own-best-way? International Journal of Production Research, 2013. 51: p. 1084-1097. 
62. Koh, S.C.L., S.M. Saad, and M.H. Jones, Uncertainty under MRP-planned manufacture review and categorization. International Journal of Production Research, 2002. 40: p. 2399-2421.

63. Xu, X.F., et al., Digital enterprise management in China: current status and future development. International Journal of Production Research, 2005. 43: p. 2593-2601.

64. Wang, C., et al., ERP research, development and implementation in China: an overview. International Journal of Production Research, 2005. 43: p. 39153932.

65. Gunasekaran, A. and E.W.T. Ngai, Knowledge management in 21st century manufacturing. International Journal of Production Research, 2007. 45: p. 2391-2418.

66. Akyuz, G.A. and M. Rehan, Requirements for forming an 'e-supply chain'. International Journal of Production Research, 2009. 47: p. 3265-3287.

67. Lea, B.-R. and H. Min, Selection of management accounting systems in JustIn-Time and Theory of Constraints-based manufacturing. International Journal of Production Research, 2003. 41: p. 2879-2910.

68. Ho, C.J., Examining dampening effects for alternative dampening procedures to cope with system nervousness. International Journal of Production Research, 2005. 43: p. 4009-4033.

69. Ho, C.-J., Measuring system performance of an ERP-based supply chain. International Journal of Production Research, 2007. 45: p. 1255-1277.

70. Ho, C.-j. and T.C. Ireland, Mitigating forecast errors by lot-sizing rules in ERP-controlled manufacturing systems. International Journal of Production Research, 2012. 50: p. 3080-3094.

71. Ho, C.-J., Exploring the compatibility of dampening procedures and lotsizing rules in MRP systems under uncertain operating environments. International Journal of Production Research, 2007. 46: p. 5097-5120.

72. Lee, S.M., et al., Successful implementations of MES in Korean manufacturing SMEs: an empirical study. International Journal of Production Research, 2012. 50: p. 1942-1954.

73. Olson, D.L., B.K. Chae, and C. Sheu, Relative impact of different ERP forms on manufacturing organisations: an exploratory analysis of a global manufacturing survey. International Journal of Production Research, 2013. 51: p. $1520-1534$.

74. Shang, S. and P.B. Seddon, A comprehensive framework for classifying the benefits of ERP systems. AMCIS 2000 proceedings, 2000: p. 39.

75. Aloini, D., R. Dulmin, and V. Mininno, Risk assessment in ERP projects. Information Systems, 2012. 37(3): p. 183-199.

76. Migdadi, M.M. and M.K.S.A. Zaid, An empirical investigation of knowledge management competence for enterprise resource planning systems success insights from Jordan. International Journal of Production Research, 2016. 54: p. 5480-5498. 
77. Venkatesh, V., S.A. Brown, and H. Bala, Bridging the qualitativequantitative divide: Guidelines for conducting mixed methods research in information systems. MIS quarterly, 2013. 37(1).

78. Purohit, G., M. Jaiswal, and M. Pandey, Challenges involved in implementation of ERP on demand solution: Cloud computing. International Journal of Computer Science Issues, 2012. 9(4): p. 481-489.

79. Peng, G.C.A. and C. Gala, Cloud ERP: a new dilemma to modern organisations? Journal of Computer Information Systems, 2014. 54(4): p. 2230.

80. Bibi, S., D. Katsaros, and P. Bozanis, Business application acquisition: onpremise or SaaS-based solutions? IEEE software, 2012. 29(3): p. 86-93.

81. Su, Y.-f. and C. Yang, Why are enterprise resource planning systems indispensable to supply chain management? European Journal of Operational Research, 2010. 203(1): p. 81-94.

82. Gecevska, V., et al., Product lifecycle management through innovative and competitive business environment. Journal of Industrial Engineering and Management, 2010. 3(2): p. 323-336.

83. Griffin, J., BI and ERP integration: Five critical questions. Information Management, 2007. 17(5): p. 6.

84. Chou, D.C., H. Bindu Tripuramallu, and A.Y. Chou, BI and ERP integration. Information Management \& Computer Security, 2005. 13(5): p. 340-349.

85. Ram, J., D. Corkindale, and M.-L. Wu, Implementation critical success factors (CSFs) for ERP: Do they contribute to implementation success and postimplementation performance? International Journal of Production Economics, 2013. 144(1): p. 157-174.

86. Ram, J. and D. Corkindale, How "critical” are the critical success factors (CSFs)? Examining the role of CSFs for ERP. Business Process Management Journal, 2014. 20(1): p. 151-174.

87. Madapusi, A. and D. D'Souza, The influence of ERP system implementation on the operational performance of an organization. International Journal of Information Management, 2012. 32(1): p. 24-34.

88. Powell, D., et al., The concurrent application of lean production and ERP: Towards an ERP-based lean implementation process. Computers in Industry, 2013. 64(3): p. 324-335.

89. Barney, J., Firm resources and sustained competitive advantage. Journal of management, 1991. 17(1): p. 99-120.

90. Porter, M.E. and V.E. Millar, How information gives you competitive advantage. 1985, Harvard Business Review, Reprint Service.

91. Teece, D., M. Peteraf, and S. Leih, Dynamic Capabilities and Organizational Agility: Risk, Uncertainity, and Strategy in the Innovation Economy. California Management Review, 2016. 58(4): p. 13-35.

92. Williamson, O.E., The economics of organization: The transaction cost approach. American journal of sociology, 1981: p. 548-577.

93. Williamson, O.E., Transaction-cost economics: the governance of contractual relations. Journal of law and economics, 1979: p. 233-261. 
94. Nelson, R.R., P.A. Todd, and B.H. Wixom, Antecedents of information and system quality: an empirical examination within the context of data warehousing. Journal of Management Information Systems, 2005. 21(4): p. 199-235.

95. DeLone, W.H. and E.R. McLean, Information systems success: the quest for the dependent variable. Information Systems Research, 1992. 3(1): p. 60-95.

96. Delone, W.H., The DeLone and McLean model of information systems success: a ten-year update. Journal of Management Information Systems, 2003. 19(4): p. 9-30.

97. Orlikowski, W.J., Sociomaterial practices: Exploring technology at work. Organization studies, 2007. 28(9): p. 1435-1448.

98. Melville, N., K. Kraemer, and V. Gurbaxani, Review: Information Technology and Organizational Performance: An Integrative Model of IT Business Value. MIS Quarterly, 2004. 28(2): p. 283-322.

99. Wixom, B.H., B. Yen, and M. Relich, Maximizing value from business analytics. MIS Quarterly Executive, 2013. 12: p. 111-123. 